\title{
PERTANGGUNGJAWABAN PIDANA TERHADAP KORPORASI SEBAGAI PELAKU TINDAK PIDANA DALAM UNDANG-UNDANG PEMBERANTASAN TINDAK PIDANA KORUPSI
}

\author{
Ni Made Kusuma Wardhani, Fakultas Hukum Universitas Udayana, e-mail: \\ nimadekusumawardhani@yahoo.com \\ Dewa Made Suartha, Fakultas Hukum Universitas Udayana, e-mail: \\ dwsuartha@gmail.com
}

doi: https://doi.org/10.24843/KS.2020.v08.i09.p08

\begin{abstract}
ABSTRAK
Tujuan studi ini untuk mendeskripsi dan menganalisis pertanggungjawaban pidana korporasi serta penentuan korporasi sebagai pelaku tindak pidana korupsi berdasarkan UU PTPK. Studi ini menggunakan metode penelitian hukum normatif dengan menggunakan pendekatan perundang-undangan dan analisis konsep hukum. Hasil studi menunjukkan bahwa dalam pembebanan pertanggungjawaban pidana masih berlaku asas "green straf zonder schuld" dengan menggunakan doktrin identifikasi. Selanjutnya tidak semua pasal dalam UU PTPK berdasarkan Pasal 1 ayat (3) UU PTPK dapat dimintakan pertanggungjawaban pidana terhadap korporasi sehingga diperlukan penafsiran lebih lanjut.
\end{abstract}

Kata Kunci: Pertanggungjawaban; Pidana; Korporasi; Korupsi

\begin{abstract}
The purpose of this study is to description and analyze corporate criminal liability as well as corporate determination as perpetrators of corruption crimes under the law on corruption eradication. This study uses normative legal research methods using statutory approaches and analysis of legal concepts. The results showed that in the loading of criminal liability still applies the principle of "green Straf zonder Schuld" Using the doctrine of identification. Furthermore, not all articles in the law on corruption eradication pursuant to article 1 paragraph (3) of the law on corruption eradication may be asked for criminal liability against the corporation so that further interpretation is required.
\end{abstract}

Key Words: Criminal; Corporation; Corruption

\section{Pendahuluan}

\subsection{Latar Belakang Masalah}

Tindak pidana salah satunya korupsi diklasifikasikan kedalam kejahatan luar biasa atau sering disebut "extra ordinary crimes"1 di Indonesia semenjak tahun 2002. Dikarenakan tindak pidana korupsi semakin marak dan pemberlakuannya semakin sistematis sehingga melanggar hak-hak ekonomi serta sosial yang ada di masyarakat maka diberlakukan Undang-Undang Republik Indonesia Nomor 31 Tahun 1999 tentang Pemberantasan Tindak Pidana Korupsi jo. Undang-Undang Republik Indonesia

1 Wijaya, A. "Peninjauan Yuridis pada Pertanggungjawaban Korporasi Tindak Pidana Korupsi." Jurnal Online Mahasiswa Fakultas Hukum Universitas Riau 1, No. 2 (2014): 1-15, 2. 
Nomor 20 Tahun 2001 tentang Perubahan atas Undang-Undang Nomor 31 Tahun 1999 tentang Pemberantasan Tindak Pidana Korupsi (selanjutnya disingkat UU PTPK).

Ketentuan UU PTPK diberlakukan didasari kepada pertimbangan bahwa kerugian perekonomian negara atau keuangan milik negara atas hasil tindak pidana korupsi menyebabkan penghambatan di dalam pembangunan nasional, kemudian perlunya penegakan hukum guna memberantas adanya tindak pidana korupsi yang terjadi di negara Indonesia.

Adanya hubungan keterkaitan antara perubahan sosial, modernisasi dan pembangunan satu dengan yang lainnya. Hubungan tersebut diantaranya adalah terkait perubahan sosial dalam suatu bangsa diakibatkan atau disebabkan oleh dijalankannya modernisasi dan pembangunan sosial.

Globalisasi memberi dampak positif bagi kemajuan negara namun disisi lain juga membawa permasalahan baru yakni kejahatan ekonomi yang lebih canggih ${ }^{2}$. Korporasi berperan dalam perekonomian nasional ${ }^{3}$ serta berkontribusi dalam hal perkembangan negara ${ }^{4}$, kini korporasi dalam menjalankan usahanya menghadapi berbagai persaingan, adanya penemuan-penemuan teknologi yang baru, usaha-usaha yang semakin meluas, beragamnya cara pemasaran guna menguasai sektor pasar. Situasi dan kondisi demikian yang menyebabkan berjalannya usaha suatu korporasi hanya memfokuskan diri kepada keuntungan sebesar-besarnnya yang menyebabkan tindakan berupa meniru, mencuri, membuat persekongkolan terhadap harga atau daerah yang dipasarkan, memalsukan, serta persaingan yang tidak sehat antara korporasi antara satu dengan yang lainnya. Pencapaian tujuan korporasi mencari keuntungan sebesarbesarnya akibat adanya persaingan usaha antara satu sama lain menyebabkan korporasi sering melakukan tindak pidana. ${ }^{5}$ Korban hasil tindak pidana korporasi ini sendiri tidak hanya berdampak kepada korporasi maupun perseorangan namun juga menyebabkan kerugian perekonomian negara atau keuangan dari suatu negara ${ }^{6}$.

Secara prinsip antara pertanggungjawaban pidana dan tindak pidana merupakan dua kriteria yang tidak dapat dipisahkan dalam penerapannya. Hal tersebut sejalan dengan pendapat Moeljatno yakni adanya pemisahan antara criminal act atau sebuah perumusan tindak pidana dan criminal responsibility atau pertanggungjawaban pidananya, mengakibatkan unsur kesalahan keluar dari perumusan tindak pidana serta kesalahan ditetapkan sebagai salah satu syarat suatu subjek hukum dapat dikenakan atau dibebankan sebuah pertanggungjawaban pidana.

Konsep yang mendasari kesalahan merupakan faktor penentu dalam pertanggungjawaban pidana dapat dilihat melalui ketentuan common law system yangmana diketahui dalam bahasa latin yakni "actus non est reus nisi mens sit rea". Menurut pandangan Wilson, maksim tersebut diterjemahkan sebaga berikut "an act is not criminal in the absence of a guility mind" (terjemahan bebas: sebuah tindakan tidak bisa

2 Yohana, Y., \& Sahari, A. "Pertanggungjawaban Pidana Korporasi Perbankan." JURNAL MERCATORIA 10 No. 1 (2017): 32-44, 33.

3 Davadi, L. B. “Pertanggungjawaban Tindak Pidana Korporasi pada Pengurus dalam Pasal 59 KUHP." Lex Et Societatis 5, No. 7 (2017): 79-84, 79.

4 Prasetyo, R. T., Ma'ruf, U., \& Mashdurohatun, A. “Tindak Pidana Korporasi dalam Perspektif Kebijakan Formulasi Hukum Pidana." Jurnal Hukum Khaira Ummah 12 No. 4 (2017): 727-741, 728.

5 Kristian, K. "Urgensi dari Pertanggungjawaban Pidana terhadap suatu Korporasi." Jurnal Hukum \& Pembangunan 44 No. 4 (2014): 575-621, 578.

6 Kristian. Hukum Pidana Korporasi: Kebijakan Integral Formulasi Pertanggungjawaban Pidana Korporasi di Indonesia (Bandung, Nuansa Aulia, 2014), 33. 
disebut dan digolongkan sebagai tindakan kriminal apabila tidak adanya kehendak jahat di dalamnya). Jadi berdasarkan hal tersebut, pengenaan pertanggungjawaban pada subjek hukum apabila subjek hukum tersebut sudah melakukan tindak pidana, juga apabila perbuatan pidana yangmana dilakukan memenuhi unsur kesalahan dalam diri pembuat. Pertentangan terhadap pemidanaan korporasi yang didasari oleh doktirn badan hukum/perkumpulan tidak dapat berbuat tindak pidana atau yang sering disebut "univertas deliquere non potest" telah dilakukan perubahan melalui penerimaan konsepsi baru yakni konsep pelaku fungsional (funtioneel daderschap) ${ }^{7}$.

Keberadaan korporasi dalam kedudukannya sebagai subjek hukum pidana serta dapat dipertanggungjawabkan menimbulkan pertanyaan kapankah sebuah korporasi dikatakan menjadi pelaku tindak pidana serta kriteria apa yang digunakan sebagai tolak ukur korporasi sudah memenuhi unsur kesalahan. Memperhatikan akibat negatif yang ditimbulkan oleh penanggulangan korporasi melalui sarana hukum pidana, maka wajar apabila ditunjukkan upaya penanggulangan kejahatan korporasi melalui beragam teori pertanggungjawaban korporasi guna mempermudah pembuktian pertanggungjawaban pidana korporasi.

Tindak pidana korupsi yang semakin berkembang mengikuti arus perkembangan jaman mengakibatkan tindak pidana korupsi pada masa kini berkembang di berbagai sektor, yang mana tidak hanya diperbuat oleh subjek hukum orang namun dilakukan juga oleh subjek hukum berupa korporasi. Indonesia kini menduduki masa dimana kejahatan yang dilakukan oleh korporasi yakni adanya kolusi diantara pemegang kekuasaan politik dengan pemegang kekuasaan ekonomi.

Menangani pemberantasan korupsi di Indonesia oleh korporasi masih belum maksimal dijerat oleh aparat penegak hukum di Indonesia. Masalah pertama terkait bagaimana mengkontruksi kesalahan dari suatu korporasi berupa kealpaan dan kesengajaan, dikarenakan unsur kesalahan adalah kriteria guna bisa dibebankannya pertanggungjawaban dari sebuah korporasi. Mengkontruksi kesalahan diisyaratkan terdapat unsur kesengajaan, dimana sebuah subjek hukum mempunyai niat dalam melakukan sebuah tindak pidana tertentu, maka dari itu sebuah unsur kesalahan dalam tindakan subjek hukum dapat terpenuhi oleh subjek hukum orang dalam hal ini tercantum didalam Kitab Undang-Undang Hukum Pidana kemudian disebut "KUHP". Penerapan unsur kesalahan dalam sebuah subjek hukum korporasi sulit dalam penerapannya dikarenakan korporasi bukanlah subjek hukum orang yang dapat memenuhi unsur kesalahan tersebut.

Masalah kedua kasus pidana yangmana subjek hukumnya adalah sebuah korporasi yang diajukan dan dapat dijerat dalam hukum pidana hingga kini terbatas dikarenakan sulitnya pembuktian kesalahan korporasi. Kesalahan korporasi sering menjadi permasalahan dikarenakan adanya kendala dalam pembuktiannya, oleh karena itu adanya perbedaan bentuk pertanggungjawaban pidana korporasi berdasarkan beberapa teori. Penyamaan pemikiran teori yang tepat dipergunakan dalam pertanggungjawaban pidana korporasi merupakan kriteria yang tepat dan memiliki peranan yang penting guna membuktikan perkara dalam persidangan sehingga memudahkan aparat penegak hukum saat tahapan pembuktian dari proses pemeriksaaan hingga penentuan putusan.

Masalah ketiga, adanya permasalahan yuridis dalam UU PTPK yakni norma yang kabur atau tidak jelas atau "vague van normen" kekaburan norma terlihat dalam

7 Bryantonio, M. "Kebijakan Formulasi Pidana bagi Tindak Pidana Korupsi Korporasi terkait Tidak Dibayarnya Denda." Unnes Law Journal 2 No. 1 (2013): 20-26, 21. 
ketentuan subjek hukum melalui Pasal 1 angka 3 UU PTPK. Beberapa pasal dalam UU PTPK menggunakan unsur "setiap orang" namun tidak semua pasal tersebut dapat dimintakan pertanggungjawaban terhadap korporasi. UU PTPK disini tidak menjabarkan dalam satu kesatuan terkait tindakan pidana jenis apa yang bisa diperbuat serta dibebankan pertanggungjawaban pidana pada suatu korporasi maka dari itu diperlukankan adanya penafsiran untuk menyatakan tindak pidana mana saja yang bisa dipertanggungjawabkan oleh sebuah korporasi sebagai subjek hukum pidana.

\subsection{Rumusan Masalah}

Berdasarkan uraian tersebut, rumusan masalah yang diangkat penulis diantaranya:

1. Bagaimanakah konsep pertanggungjawaban pidana korporasi dalam UU PTPK?

2. Bagaimanakah penentuan korporasi sebagai pelaku tindak pidana korupsi berdasarkan UU PTPK?

\subsection{Tujuan Penulisan}

Penelitian ini memiliki tujuan untuk mendeskripsi dan menganalisis pertanggungjawaban pidana korporasi serta mendeskripsi dan menganalisis penentuan korporasi sebagai pelaku tindak pidana korupsi berdasarkan UU PTPK.

\section{Metodelogi Penelitian}

Metodelogi penelitian yang dipergunakan didalam penelitian disini yakni metode penelitian hukum normatif. Metodelogi penelitian hukum normatif yakni metode yang titik berat perhatiannya kepada data sekunder. Adapun metode penelitian hukum normatif menempatkan hukum sebagai pondasi sistem norma hukum serta penghimpunan datanya melalui penggalian kepustakaan/penggalian dokumen. Penelitian ini menggunakan pendekatan analisis konsep hukum dan pendekatan perundang-undangan. Penelitian ini titik berat perhatiannya kepada data-data sekunder, yang berisi bahan hukum primer dan bahan hukum sekunder. Teknik dalam pengumpulan bahan-bahan hukum yang dipergunakan yakni teknik sistem kartu (card systems). Teknik dalam menganalisis bahan hukum yang dipergunakan dalam analisa penelitian ini antara lain deskriptif, argumentatif dan evaluatif.

\section{Hasil Dan Pembahasan}

\subsection{Pertanggungjawaban Pidana Korporasi dalam UU PTPK}

Berdasarkan aliran ultilitarianisme yang mana tujuan hukum diletakkan sebagai kemanfaatan, tujuan hukum disini ditafsirkan sebagai kebahagiaan, sejalan dengan perkembangan hukum pidana di Indonesia menyatakan pertanggungjawaban pidana dapat dibebenakan kepada korporasi, tidak lagi subjek hukum pidana hanyalah manusia seperti yang tercantum dalam KUHP. Memperhatikan akibat negatif yang ditimbulkan oleh korporasi yang melakukan tindakan pidana khususnya menyebabkan kerugian perekonomian negara atau keuangan negara maka kebijakan dapat dipertanggungjawabkan secara pidana terhadap korporasi memberikan kemanfaatan terhadap penegakan hukum di Indonesia berupa tertib hukum khususnya kepada korporasi dalam menjalankan usahanya agar tidak merugikan perekonomian negara atau keuangan negara. Praktik bisnis yang bersih dari korupsi akan melindungi korporasi dan setiap insan korporasi, baik dari pegawai hingga pimpinan. Korporasi dan insan korporasi akan dari dampak negatif misalnya hukuman penjara (badan), kerugian finansial, rusaknya nama baik (reputasi), kehilangan klien/pelanggan, serta 
besarnya biaya investigasi dan litigasi bila perkara dibawa ke dalam ranah penegakan hukum.

Corporate criminal liability diatur dalam Pasal 20 ayat (2) UU PTPK yakni tindak pidana korupsi dapat diperbuat oleh suatu korporasi apabila dalam tindak pidana tersebut orang yang melakukan didasari oleh adanya hubungan kerja atau hubungan lainnya, tindakan tersebut dilakukan dalam lingkup suatu koporasi secara sendiri maupun secara bersama-sama. Pasal 20 ayat (2) UU PTPK tersebut apabila ditinjau berdasarkan teori pertanggungjawaban pidana korporasi, maka pasal tersebut menggunakan bentuk pertanggungjawaban berdasarkan doctrine of identification.

Orang sebagai subjek hukum dapat dijatuhi pidana tidak cukup apabila seseorang tersebut memenuhi kriteria perbuatan yakni melakukan tindak pidana sesuai dengan delik dalam hukum pidana, syarat dijatuhinya pidana terhadap seseorang belum memenuhi apabila melihat hanya sebatas unsur tersebut. Didasari pada teori pertanggungjawaban pidana, dalam penjatuhan pidana terhadap subjek hukum dibutuhkan adanya beberapa persyaratan diantaranya adanya unsur bersalah atau kesalahan terhadap orang yang melakukan perbuatan tersebut atau dikenal pula dengan "subjective guilt". Diberlakukan "asas tiada pidana tanpa kesalahan"8 atau sering dikenal dengan "geen straf zonder schuld" dalam hal ini. Kesalahan itu sendiri dijabarkan atas unsur-unsur yakni sebagai berikut:

1. Terhadap pelaku atau pembuat harus memiliki kemampuan bertanggungjawab (schuldfahigkeit atau zurechnungsfahigkeit): dapat diartikan bahwa dalam diri pelaku memenuhi kriteria kejiwaan yang normal;

2. Adanya hubungan batin diantara perbuatan yang dilakukan dengan pembuatnya berupa bentuk-bentuk kesalahan diantaranya kealpaan (culpa) atau berupa kesengajaan (dolus);

3. Terhadap pembuat atau pelaku atas perbuatannya tidak dapat dikenakan alasan pemaaf atau yang menghapus kesalahan. ${ }^{9}$

Apabila tiga hal tersebut terpenuhi, maka dapat dinyatakan bersalah serta dapat dibebankan pertanggungjawaban pidana sehingga bisa dipidana terhadap subjek hukum yang bersangkutan.

Penuntut umum harus bisa mengidentifikasikan siapa subjek yang melakukan tindak pidana untuk dapat membebankan pertanggungjawan pidana berdasarkan doctrine of identification kepada suatu korporasi. Pembebanan pertanggungjawaban dapat dilakukan pada suatu korporasi pada saat tindak pidana dilakukan oleh pihakpihak korporasi yang merupakan "directing mind" atau "alter ego"10. Mens rea seseorang atau individu adalah mens rea dari perusahaan dikarenakan dalam tindakan individu tersebut ada kaitannya dengan tindakan yang diambil perusahaan, jadi apabila seseorang individu bertindak dalam wewenangnya atas nama dan atau menjalankan suatu perusahaan maka mens rea dari individu tersebut adalah mens rea perusahaan.

Michael Allen berpendapat berkaitan dengan hal tersebut "The corporation will only be liable where the person identified with it was acting within the scope of his office; it will not

8 Padil, P. "Karakteristik Pertanggungjawaban Pidana terhadap Korporasi dalam Tindak Pidana Korupsi." Jurnal IUS Kajian Hukum dan Keadilan 4 No. 1 (2016): 44-59, 29.

9 Runtuwene, R. R. R. "Pertanggungjawaban Pidana Korporasi suatu Perkembangan Tindak Pidana." LEX ET SOCIETATIS 5 No. 2 (2017): 124-131, 128.

10 Cahaya, Suhandi. Kejahatan Korporasi (Jakarta, Universitas Jayabaya Press, 2013), 101. 
be liable for acts which he did in his personal capacity". 11 Tanggungjawab korporasi dapat diterapkan apabila perbuatan perusahaan mengidentifikasi adanya perbuatan seseorang didalamnya yang bertindak pada ruang lingkup jabatan, kemudian suatu korporasi tidak dapat dibebankan pertanggungjawaban bila perbuatan tersebut merupakan tindakan dalam konteks dan kapasitas diri secara pribadi12.

Directing mind dalam suatu korporasi dapat terlihat dan diketahui berdasarkan anggaran dasar dalam korporasi tersebut. Selanjutnya diketahui pula berdasarkan suratsurat pengangkatan jabatan dalam surat keputusan pengurus dalam pengisian jabatan serta pemberian kewenangan dalam menjalakan tugas serta kewajiban dalam jabatannya ${ }^{13}$.

Dalam menetapkan korporasi dalam kedudukannya sebagai pelaku tindak pidana dan dibebankan pertanggungjawaban pidana, berdasarkan hal tersebut diatas maka asas kesalahan yakni tiada pidana tanpa kesalahan atau yang dikenal sebagai "green straf zonder schuld" masih berlaku mutlak. Alasan utama menerapkan asas ini yakni demi perlindungan masyarakat karena sulitnya pembuktian atas unsur kesalahan ${ }^{14}$. Mengenai penjatuhan sanksi atau pidana yang dikenakan kepada korporasi dan atau pengurusnya, disini konsep pertanggungjawabannya diterapkan dengan doktrin identifikasi, sehingga pidana yang dapat diterapkan sesuai dengan ketentuan UU PTPK.

Terkait perbuatan tindak pidana korupsi oleh subjek hukum korporasi, berdasarkan Pasal 20 ayat (1) UU PTPK, penuntutan dan penjatuhan suatu pidana dapat dibebankan kepada korporasi dan atau kepada pengurus korporasi tersebut. Diakuinya korporasi sebagai subjek hukum pidana tidak berarti penjatuhan pidana dapat disamakan sesuai Pasal 10 KUHP. Pengenaan pidana terhadap suatu korporasi dapat dibebankan pidana pokok yang mana telah diatur dalam Pasal 20 ayat (7) UU PTPK dan pidana tambahan yang mana telah diatur Pasal 18 ayat (1) UU PTPK

\subsection{Penentuan Korporasi sebagai Pelaku Tindak Pidana Korupsi berdasarkan UU PTPK}

Pandangan dari aliran/madzhab hukum positif atau positivisme hukum memandang tiada hukum lain kecuali pemerintah penguasa atau "law is command of lawgivers", dalam aliran hukum positif atau dikenal dengan aliran hukum legisme menegaskan bahwasanya hukum sering dikaitkan dalam perundang-undangan. Berdasarkan aliran ini hukum merupakan norma-norma yang sumbernya berasal dari kewenangan yang formal atau informal dalam suatu lembaga yang memiliki kewenangan atas hal tersebut maupun berasal dari lembaga pemerintahan yang tertinggi. Aliran hukum legisme memposisikan dirinya pada hukum tertulis (law in book). Dalam mazhab positivisme kepastian hukum adalah yang utama, apabila dikaitkan dengan tindak pidana korupsi yang diperbuat oleh korporasi, pengaturan secara jelas dan tepat sangat mempengaruhi keefektifan pemberlakuan hukum dalam masyarakat.

11 Supit, C. B. M. "Pertanggungjawaban Pidana Korporasi dalam Peraturan PerundangUndangan Indonesia." LEX ADMINISTRATUM 3 No. 6 (2015): 63-72, 69.

12 Fahamsyah, E., \& Suarda, I. C. W. "Implementasi Teori Pertanggungjawaban Pidana Korporasi terkait dengan Kejahatan Korporasi." Mimbar Hukum 18 (2006): 1-15, 5.

13 Amdani, Y. "Formulasi Hukum Pidana dalam Pertanggung Jawaban Pidana Korporasi Kasus Tindak Pidana Korupsi." Jurnal Hukum Samudra Keadilan 12 No. 2 (2017): 186-198, 190.

14 Martha, I. D. A. G. M., \& Suartha, I. D. M. "Kebijakan Hukum Pidana Dalam Pertanggungjawaban Tindak Pidana Korporasi Di Indonesia." Kertha Wicaksana: Sarana Komunikasi Dosen dan Mahasiswa 12 No. 1 (2018): 1-10. 3. 
Melihat UU PTPK, terdapat permasalahan yuridis dalam UU PTPK yakni adanya norma yang kabur atau tidak jelas atau "vague van normen" kekaburan norma terlihat dalam ketentuan subjek hukum melalui Pasal 1 angka 3 UU PTPK yang menyatakan bahwa yang dimaksud setiap orang dalam UU PTPK termasuk di dalamnya perseorangan atau termasuk korporasi. Beberapa pasal dalam UU PTPK menggunakan unsur "setiap orang" namun tidak semua pasal tersebut dapat dimintakan pertanggungjawaban terhadap korporasi. UU PTPK tidak melakukan penjabaran terhadap satu kesatuan pasal terkait tindakan apa saja yang dapat diperbuat serta dimintai pertanggungjawaban pada suatu korporasi selanjutnya diperlukan penafsiran untuk menentukan tindak pidana mana saja yang dapat dipertanggungjawabkan oleh korporasi.

Machteld Boot mengatakan bahwa "Every legal norm needs interpretation" (Terjemahan bebas: setiap norma hukum memerlukan sebuah interpretasi). Senada dengan Boot, van Bemmelen dan van Hatum secara tegas menyatakan bahwa "Elke geschreven wetgeving behoeft interpretative" (dalam setiap aturan perundang-undangan tertulis membutuhkan interpretasi). Begitu pentingnya penafsiran dalam pengembanan hukum ${ }^{15}$, sebuah hukum tidak dapat berjalan apabila tidak dilakukan penafsiran, sebagaimana dikatakan oleh Satjipto Rahardjo berdasarkan hal tersebut maka diperlukan pemaksaan terhadap penafsiran untuk membentuk keadilan dan lebih membumi. Kegiatan penafsiran ini tidak dilakukan oleh aparat penegak hukum saja, namun dilakukan juga oleh peneliti hukum. Tujuannya adalah untuk mencari arti yang sebenarnya atau vim ac postastem dari kehendak pembuat undang-undang terhadap suatu rumusan pasal tertentu.

Pasal 1 ayat 3 UU PTPK dalam hal menjabarkan ketentuan unsur "setiap orang" terhadap perbuatan-perbuatan antara lain tindak pidana korupsi berupa dalam hal perbuatan memperkaya diri sendiri atau orang lain sehingga mengakibatkan kerugian keuangan negara, penyalahgunaan kewenangan atau jabatan sehingga menyebabkan kerugian keuangan negara, memberi suap serta hadiah dalam jabatannya serta tindak pidana korupsi yang diatur dalam ketentuan di dalam UU PTPK diantaranya diatur dalam Pasal 2, Pasal 3, Pasal 5 ayat (1), Pasal 6 ayat (1), Pasal 7 ayat (1), Pasal 13 dan Pasal 14 UU PTPK. Pemufakatan jahat atau pembantuan dalam melakukan tindak pidana korupsi yang diatur dalam Pasal 15 dan Pasal 16 UU PTPK. Pasal 21 UU PTPK terkait tindak pidana yang memiliki hubungan dengan tindak pidana korupsi yakni kegiatan mencegah, menggagalkan atau merintangi baik secara langsung maupun tidak langsung terhadap proses penyidikan, penunututan dan pemeriksaan di pengadilan serta Pasal 22 UU PTPK terkait memberikan atau tidak memberikan keterangan secara tidak benar.

Berdasarkan penafsiran sistematis atau logis, yaitu suatu ajaran penafsiran yang menafsirkan suatu undang-undang dengan cara keseluruhan sistem hukum atau undang-undang lain atau peraturan hukum saling dihubungkan satu sama lain. Apabila dilakukan penafsiran secara sistematis maka berdasarkan pasal-pasal UU PTPK tidak semua tindak pidana yang memiliki unsur "setiap orang" dapat diperbuat oleh korporasi sehingga dapat dimintakan pertanggungjawaban pidana terhadap korporasi tersebut, melainkan hanya kepada subjek hukum berupa orang dalam melakukan tindak pidana.

15 Meuwissen. Pengembanan Hukum, Ilmu Hukum, Teori Hukum, Dan Filsafat Hukum. Cet. Ke V, terjemahan dari B. Arief Sidharta. (Bandung, Refika Aditama, 2018), vii. 
Kekaburan dalam permintaan pertanggungjawaban pidana terhadap korporasi terkait tindak pidana yang memiliki unsur "setiap orang" diantaranya:

1. Pasal 3 UU PTPK

Pasal 3 UU PTPK mengatur mengenai adanya perbuatan dalam jabatan atau kedudukannya menyalahgunakan kewenangan sehingga menyebabkan kerugian perekonomian negara atau keuangan negara.

Apabila ditafsirkan secara sistematis, KUHP tidak menjabarkan pengertian dari pejabat atau kedudukan, namun didalam Pasal 92 KUHP menjabarkan pengertian pejabat, didalamnya termasuk orang-orang yangmana telah dipilih di dalam sebuah pemilihan didasari oleh aturan umum, juga termasuk yang tidak disebabkan oleh sebuah pemilihan menjadi anggota badan perwakilan rakyat, badan pemerintahan, atau badan pembentuk undang-undang.

Kedudukan korporasi yang bukan orang sebagai manusia (natural person) menyebabkan unsur jabatan atau kedudukan di dalam perumusan delik Pasal 3 UU PTPK tidak dapat diterapkan karena unsur jabatan atau kedudukan adalah unsur yang dapat diterapkan kepada orang sebagai manusia bukan kepada korporasi. Berdasarkan ketentuan tersebut maka unsur "setiap orang" yang tercantum pada rumusan delik Pasal 3 UU PTPK hanya ditunjukkan bagi subjek hukum orang saja tidak termasuk didalamnya korporasi dikarenakan adanya pembatasan di dalam unsur "jabatan atau kedudukan" tersebut.

2. Pasal 21 UU PTPK

Perbuatan lain yang tidak dapat dipertanggungjawabkan kepada korporasi yakni Pasal 21 UU PTPK terkait tindak pidana lainnya yang ada hubungannya dengan tindak pidana korupsi yakni tindakan mencegah, menggagalkan atau merintangi baik secara tidak langsung maupun langsung terhadap suatu penyidikan, penuntutan dan pemeriksaan di persidangan sebagaimana dinyatakan di dalam Pasal 21 UU PTPK. Dikarenakan unsur yang berada pada delik tersebut lebih tepat diterapkan kepada subjek hukum berupa orang sebagai manusia (natural person) bukan terhadap suatu korporasi. Maka berdasarkan hal tersebut unsur "setiap orang" dalam delik tersebut tidak dapat dikualifikasikan sebagai pasal yang dapat diterapkan kepada korporasi melainkan hanya dapat diterapkan kepada subjek hukum berupa orang.

3. Pasal 22 UU PTPK

Perbuatan lain yang tidak dapat dipertanggungjawabkan kepada korporasi yakni Pasal 21 UU PTPK terkait tindak pidana lainnya yang ada hubungannya dengan tindak pidana korupsi yakni terkait tidak dilakukannya pemberian suatu keterangan yang tidak benar yangmana dinyatakan dalam Pasal 22 UU PTPK dikarenakan unsur yang berada pada delik tersebut lebih tepat diterapkan kepada subjek hukum berupa orang sebagai manusia (natural person) bukan terhadap suatu korporasi. Maka berdasarkan hal tersebut unsur "setiap orang" dalam delik tersebut tidak dapat dikualifikasikan sebagai pasal yang dapat diterapkan kepada korporasi melainkan hanya dapat diterapkan kepada subjek hukum berupa orang. Berdasarkan analisa tersebut diatas, ketentuan Pasal 1 angka 3 UU PTPK yang menyatakan bahwa yang dimaksud setiap orang dalam UU PTPK termasuk di dalamnya perseorangan atau termasuk korporasi, tidak mencakup semua pasal dengan frasa tersebut dapat dimintakan pertanggungjawaban terhadap korporasi sebagai subjek hukum.

Ketentuan Pasal 1 angka 3 UU PTPK tidak dapat diterapkan secara mutlak pada Pasal 3, Pasal 21 dan Pasal 22 UU PTPK karena apabila diinterpretasikan, pasal tersebut 
hanya dapat diterapkan pada orang sebagai subjek hukum dan tidak dapat diterapkan kepada korporasi dalam hal melakukan tindak pidana.

\section{Kesimpulan}

Kesimpulan yang dapat ditarik berdasarkan pembahasan diatas, UU PTPK mengatur mengenai pertanggungjawaban pidana korporasi dalam Pasal 20 ayat (2). Berdasarkan ketentuan pasal tersebut korporasi sebagai subjek hukum dan pelaku tindak pidana dan dapat dibebankan pertanggungjawaban pidana, asas kesalahan yakni tiada pidana tanpa kesalahan atau dikenal dengan "green straf zonder schuld" masih berlaku mutlak. Mengenai penjatuhan sanksi atau pidana yang dikenakan kepada korporasi dan atau pengurusnya, disini konsep pertanggungjawabannya diterapkan dengan doktrin identifikasi, sehingga pidana yang dapat diterapkan sesuai dengan ketentuan UU PTPK. Diperlukan penafsiran secara khusus terkait tindak pidana yang dapat dipertanggungjawabkan kepada korporasi karena UU PTPK tidak menjabarkan ketentuan pasal tindak pidana yang dapat dilakukan oleh suatu korporasi. Tidak semua pasal dalam UU PTPK mengacu berdasarkan Pasal 1 ayat (3) UU PTPK dapat dimintakan pertanggungjawaban pidana terhadap korporasi diantaranya Pasal 3, Pasal 21 dan Pasal 22 UU PTPK.

\section{DAFTAR PUSTAKA}

\section{$\underline{\text { Buku }}$}

Cahaya, Suhandi. Kejahatan Korporasi (Jakarta, Universitas Jayabaya Press, 2013).

Kristian. Hukum Pidana Korporasi: Kebijakan Integral Formulasi Pertanggungjawaban Pidana Korporasi di Indonesia (Bandung, Nuansa Aulia, 2014).

Meuwissen. Pengembanan Hukum, Ilmu Hukum, Teori Hukum, Dan Filsafat Hukum. Cet. Ke V, terjemahan dari B. Arief Sidharta. (Bandung, Refika Aditama, 2018).

\section{Jurnal}

Amdani, Y. "Formulasi Hukum Pidana dalam Pertanggung Jawaban Pidana Korporasi Kasus Tindak Pidana Korupsi." Jurnal Hukum Samudra Keadilan 12 No. 2 (2017): 186198.

Bryantonio, M. "Kebijakan Formulasi Pidana bagi Tindak Pidana Korupsi Korporasi terkait Tidak Dibayarnya Denda." Unnes Law Journal 2 No. 1 (2013): 20-26.

Davadi, L. B. "Pertanggungjawaban Tindak Pidana Korporasi pada Pengurus dalam Pasal 59 KUHP." Lex Et Societatis 5, No. 7 (2017): 79-84.

Fahamsyah, E., \& Suarda, I. C. W. "Implementasi Teori Pertanggungjawaban Pidana Korporasi terkait dengan Kejahatan Korporasi." Mimbar Hukum 18 (2006): 1-15, 5.

Kristian, K. "Urgensi dari Pertanggungjawaban Pidana terhadap suatu Korporasi." Jurnal Hukum \& Pembangunan 44 No. 4 (2014): 575-621.

Martha, I. D. A. G. M., \& Suartha, I. D. M. "Kebijakan Hukum Pidana Dalam Pertanggungjawaban Tindak Pidana Korporasi Di Indonesia." Kertha Wicaksana: Sarana Komunikasi Dosen dan Mahasiswa 12 No. 1 (2018): 1-10.

Padil, P. “Karakteristik Pertanggungjawaban Pidana terhadap Korporasi dalam Tindak Pidana Korupsi." Jurnal IUS Kajian Hukum dan Keadilan 4 No. 1 (2016): 44-59.

Prasetyo, R. T., Ma'ruf, U., \& Mashdurohatun, A. "Tindak Pidana Korporasi dalam Perspektif Kebijakan Formulasi Hukum Pidana." Jurnal Hukum Khaira Ummah 12 No. 4 (2017): 727-741. 
Runtuwene, R. R. R. "Pertanggungjawaban Pidana Korporasi suatu Perkembangan Tindak Pidana." LEX ET SOCIETATIS 5 No. 2 (2017): 124-131.

Supit, C. B. M. "Pertanggungjawaban Pidana Korporasi dalam Peraturan PerundangUndangan Indonesia." LEX ADMINISTRATUM 3 No. 6 (2015): 63-72.

Wijaya, A. "Peninjauan Yuridis pada Pertanggungjawaban Korporasi Tindak Pidana Korupsi." Jurnal Online Mahasiswa Fakultas Hukum Universitas Riau 1, No. 2 (2014): 115.

Yohana, Y., \& Sahari, A. “Pertanggungjawaban Pidana Korporasi Perbankan." JURNAL MERCATORIA 10 No. 1 (2017): 32-44.

\section{Peraturan Perundang-Undangan}

Kitab Undang-Undang Hukum Pidana.

Undang-Undang Nomor 31 Tahun 1999 tentang Pemberantasan Tindak Pidana Korupsi (Lembaran Negara Republik Indonesia Tahun 1999 Nomor 140, Tambahan Lembaran Negara Republik Indonesia Nomor 3874) sebagaimana telah diubah dengan Undang-Undang Nomor 20 Tahun 2001 tentang Perubahan atas Undang-Undang Nomor 31 Tahun 1999 tentang Pemberantasan Tindak Pidana Korupsi (Lembaran Negara Republik Indonesia Tahun 2001 Nomor 134, Tambahan Lembaran Negara Republik Indonesia Nomor 4150). 